\title{
Constelações de uma práxis pedagógica: o sensível, a linguagem, as infâncias e a memória (presenças de Walter Benjamin) na formação docente $^{1}$
}

Dilson Miklos ${ }^{2}$

\begin{abstract}
RESUMO
Linguagem, arte, infância e memória são alguns dos conceitos que o ensaio apresenta a partir do olhar de Walter Benjamin que nos acompanha na escrita a fim de extrair enunciados de um contexto voltado à formação de professores. Nesse percurso são apresentados dois conceitos que emergem da pesquisa docente, a saber: práxis poética e narrativimagem. O campo do sensível é o lócus onde aflora esse conjunto de saberes que se comunica poeticamente e que objetiva refletir sobre o currículo e práticas pedagógicas outras. Ainda, há o esforço, na companhia do filósofo berlinense, de compreender o processo da formação a partir de uma perspectiva menos totalizante e definitiva.
\end{abstract}

PALAVRAS-CHAVE: currículo; formação de professores; Walter Benjamin; narrativimagem; práxis poética.

Constellations of a pedagogical praxis: the sensible, language, childhood and memory (presences of Walter Benjamin) in teacher education

\begin{abstract}
Language, art, childhood and memory are some of the concepts that the essay presents from the perspective of Walter Benjamin who accompanies us in writing, in order to extract statements from a context focused on teacher education. In this course are presented two concepts that emerge
\end{abstract}

\footnotetext{
${ }^{1}$ Uma versão dessa reflexão foi apresentada na 39 Reunião Nacional da ANPEd, RJ, 2019, e publicada nos anais.

2 Doutor em Educação/UNIRIO. Instituto Superior de Educação do Rio de Janeiro (ISERJ). https://orcid.org/00000002-2933-7518.dilson.miklos@gmail.com.
} 
from the teaching research, namely: poetic praxis and narrativimagem. The field of the sensible is the locus where this set of knowledge that communicates poetically and which aims to reflect on the curriculum and other pedagogical practices emerges. Still, there is the effort, in the company of the Berlin philosopher, to understand the process of formation from a less totalizing and definitive perspective.

KEYWORDS: curriculum; teacher training; Walter Benjamin; narrativimagem; poetic praxis.

Constelaciones de una praxis pedagógica: lo sensible, el lenguaje, la infancia y la memoria (presencias de Walter Benjamin) en la formación del profesorado

\section{RESUMEN}

Lenguaje, arte, infancia y memoria son algunos de los conceptos que presenta el ensayo desde la perspectiva de Walter Benjamin quien nos acompaña por escrito, para extraer declaraciones de un contexto centrado en la formación del profesorado. En este curso se presentan dos conceptos que surgen de la investigación docente, a saber: praxis poética e imagen narrativa. El campo de lo sensible es el lugar donde emerge este conjunto de conocimiento que se comunica poéticamente y que tiene como objetivo reflexionar sobre el currículo y otras prácticas pedagógicas. Sin embargo, existe el esfuerzo, en compañía del filósofo de Berlín, de comprender el procesode formación desde una perspectiva menos totalizadora y definitiva.

PALABRAS CLAVE: currículum formación de profesores; Walter Benjamin; narrativimage; praxis poética.

$$
* * *
$$

A obra nasce apenas de um toque na matéria. Quero que a matéria de que é feita minha obra permaneça como ela é; o que a transforma em expressão não é nada mais que um sopro interior de plenitude cósmica.

Fora disso não há obra. Basta um toque e nada mais. 


\section{Uma clareira: arte, linguagem e memória}

As estéticas filosóficas que se debruçam a pensar com rigor o campo da arte apontam para uma direção oposta aos que conferem ao campo do sensível um domínio particular. Em outras palavras, a arte tende a ultrapassar um ponto de vista puramente estético. A forma como a arte se manifesta, nos diversos suportes e meios expressivos, tem alcance existencial, cognitivo, ético e político, tornando-se, desta forma, determinante para as interpretações de nossa subjetividade e de uma época. A arte, portanto, remete a todas as dimensões da vida, e o artista é o visionário que atravessa as linhas do tempo e do espaço, lança-se na aventura de instaurar em homens e mulheres o seu enfrentamento com a sua própria historicidade, revela ao mundo outros mundos e desvela modos outros de capturar sentidos do cotidiano.

O percurso estético de Walter Benjamin (1892-1940) ressalta a função transcendente da arte no processo histórico, ou seja, a importância e a verdade de uma obra de arte estão diretamente ligadas à sua emancipação dos elementos históricos, cuja atualidade perece. A questão central que Benjamin procura no âmago da obra de arte é o ato ou instante que se instaura a liberdade existencial e o sentido filosófico da sua presença e não uma apresentação esteticamente acabada, fechada em si mesma, de uma experiência. Arte é linguagem. A partir dessa angulação Benjamin (2013) escreve sobre a linguagem da arte:

Há uma linguagem da escultura, da pintura, da poesia. Assim como a linguagem da poesia se funda - se não unicamente, pelo menos em parte - na linguagem de nomes do homem, pode-se muito bem pensar que a linguagem da escultura ou da pintura estejam fundadas em certas espécies de linguagens das coisas para uma linguagem infinitamente superior, embora talvez pertencente à mesma esfera. Trata-se aqui de línguas sem nome, sem acústica, de línguas próprias do material; aqui é preciso pensar naquilo que as coisas têm em comum, em termos de material, em sua comunicação. De resto, a comunicação das coisas é com certeza de tal tipo de 
comunidade que lhe permite abraçar o mundo inteiro como um todo indiviso. (Ibid, p.71).

Há que se registrar que Benjamin considerava-se um filósofo da linguagem, à qual atribui uma dimensão espiritual, mística e poética. A linguagem não é, para o filósofo berlinense, uma particularidade do homem, esta assume, neste caso, uma forma particular e privilegiada de uma "linguagem geral". O mundo é linguagem. Tudo na Criação é linguagem. A realidade, portanto, é expressiva, traz consigo marcas, sensorialidades e fisionomias que estão impregnadas de sentidos que comunicam presenças espirituais no/do mundo. O filósofo da linguagem assim a define:

Nesse contexto, língua, ou linguagem, significa o princípio que se volta para a comunicação de conteúdos espirituais nos domínios em questão: na técnica, na arte, na jurisprudência ou na religião. Resumindo: toda comunicação de conteúdos espirituais é língua, linguagem, sendo a comunicação pela palavra apenas um caso particular: o da comunicação humana e do que a fundamenta ou do que se funda sobre ela (a jurisprudência, a poesia). Mas a existência da linguagem estende-se não apenas a todos os domínios de manifestação do espírito humano, ao qual, num sentido ou em outro, a língua sempre pertence, mas a absolutamente tudo. Não há evento ou coisa, tanto na natureza animada, quanto inanimada, que não tenha, de alguma maneira, participação na linguagem, pois é essencial a tudo comunicar seu conteúdo espiritual. (Ibid, p.49-51).

Ao final do ensaio Sobre a linguagem em geral e sobre a linguagem do homem, de 1916, Benjamin apresenta um conceito, como mesmo sinaliza, mais depurado de linguagem e, por mais imperfeito que ele ainda possa ser, destaca que "a linguagem de um ser é o meio em que sua essência espiritual se comunica" (Ibid, p.72). As ideias que inaugura no mundo estão impregnadas de uma atmosfera mágica, que tem no inacabamento, na fragmentação sem síntese, na indeterminação, na plasticidade e na 
multiplicidade os elementos que as constituem e as atualizam no século XXI. A sua obra não carrega um sentido absoluto e totalizante. É ruína.

Outro recorte presente nos escritos de Benjamin aponta para o conceito de memória, um patrimônio imensurável do qual só inventaríamos fragmentos. A sua materialidade é extraída na ação que se faz sobre o tempo e no tempo, sobre o espaço e no espaço. O vórtice que os meios de produção impuseram ao cotidiano contemporâneo - fenômeno este já analisado por Walter Benjamin na modernidade - destrói os suportes materiais da memória, bloqueia os caminhos da lembrança, arranca seus marcos e apaga os seus rastros. Podemos também inserir nesse processo de esquecimento as redes de informação e comunicação que intensificaram as vivências do cotidiano, maximizando o real em uma ficção ou, para ser mais preciso, em uma ilusão. A alegoria do mito da caverna de Platão parece ter encontrado, neste debate, uma nova correspondência. $\mathrm{O}$ esforço, dentre muitos outros, no contexto da disciplina de Arte e Educação, ministrada no Curso de Pedagogia, do Instituto Superior de Educação do Rio de Janeiro (ISERJ), é refazer caminhos, resgatar "pegadas", distender fronteiras e reconhecer vestígios com as práxis poéticas ${ }^{3}$.

As reminiscências também são sufocadas pela História oficial que se coloca como a celebração do ponto de vista do vencedor. A historiografia manifesta uma força nefasta que esmaga a tradição dos vencidos, ou seja, o direito à palavra das classes populares. Com as narrativimagens ${ }^{4}$ aprendemos a "andar na trilha" deixada pela memória do Outro, reconhecemos na sua reflexão uma matéria-prima para o trabalho de elaboração do nosso próprio pensamento e, por conseguinte, se constituem em uma forma outra de escrita da história e de pensar as presenças da palavra e da imagem na formação de professores.

Walter Benjamin (1994) no seu último escrito, de 1940, Sobre o conceito

\footnotetext{
${ }^{3}$ As práxis poéticas são ações e experiências sugeridas no âmbito da disciplina Arte e Educação, no curso de Pedagogia, que objetivam encarnar o discente de sua mitopoética, desvelar subjetividades e valorizar processos de criação.

${ }^{4}$ Narrativimagens é um conceito criado pelo autor que propõe a fusão entre a produção escrita e a criação imagética, pois considera que tanto uma quanto a outra, nesta experiência, são indissociáveis.
} 
da História, abole a ideia de um destino único e sinaliza que o materialismo histórico deve considerar como tarefa sua "escovar a história a contrapelo" (Ibid, p.225), ou seja, na direção contrária. A inconclusão da História é uma esperança e a memória, neste sentido, é importante, pois mantém viva a possibilidade de uma reescrita do passado, alforriando-o da sua eterna repetição. As narrativimagens assumem, de fato, um compromisso com a história, a percepção e o movimento de vida do Outro. E, neste fluxo, colocamos em evidência a existência das memórias como parte do Outro, de nós e do mundo.

"A memória é a mais épica de todas as faculdades", segundo Walter Benjamin (1994, p.210), que reflete sobre a importância da narrativa na figura do narrador, que "retira da experiência o que ele conta: sua própria experiência ou a relatada pelos outros. E incorpora as coisas narradas à experiência dos seus ouvintes" (Ibid, p. 201). Para o ensaísta alemão, o primeiro indício que vai culminar na morte da narrativa é o surgimento do romance no início do período moderno. O que difere o narrador do romancista é que este último segregou-se. "A origem do romance é o indivíduo isolado, que não pode mais falar exemplarmente sobre suas preocupações mais importantes e que não recebe conselhos e nem sabe dá-los" (Ibid, p.201). A memória se comunica com a experiência e, nesse intercâmbio, mostram-se indissociáveis. De fato, a contemporaneidade apresenta desafios neste campo, o que não significa que hoje não existam mais experiências, mas estas se concretizam fora do sujeito. A experiência à qual Benjamin se refere não é guiada pela consciência, traz em seu bojo o sentido histórico do acontecimento. A experiência que se molda na relação sujeito e objeto é atrofiada. A esse modo mais restrito de estabelecer conexões com o mundo, o pensador da modernidade nomeará de vivência.

Em Infância em Berlim por volta de 1900 (Berliner Kindheit um 1900), o rabino marxista ${ }^{5}$ (1995) faz um mergulhono mundo das “miudezas", trazendo

\footnotetext{
${ }^{5}$ Compreende parte do título de um capítulo "O Rabino Marxista: Walter Benjamin”, do livro A Ideologia daEstética, de Terry Eagleton, que analisa a estética de Walter Benjamin no contexto do marxismo.
} 
as impressões cotidianas e subjetivas da sua criança no limiar do século XX, em sua cidade natal, a Berlim de outrora. Concluído em 1932, o texto é uma série de fragmentos que apresenta uma escrita inspirada no trabalho de escavação do arqueólogo: o que vem à superfície é a imagem da cidade em miniatura, os relatos escolares, as narrativas das viagens, as brincadeiras, como caçar borboletas, os desejos e as situações experimentadas pela criança Walter. Chegando Atrasado, um dos lampejos que integram Infância em Berlim, relata uma experiência comum a todo estudante:

O relógio no pátio da escola parecia ter sido danificado por minha culpa. Indicava "atrasado". No corredor penetravam murmúrios de consultas secretas vindos das portas das salas de aula que eu roçava ao passar. Atrás delas, professores e alunos eram camaradas. Ou então tudo permanecia em silêncio, como se alguém fosse guardado. Inaudivelmente apalpei a maçaneta. $\mathrm{O}$ sol inundava o lugar onde eu me achava. Foi assim que violei meu dia que mal começara, e entrei. Ninguém parecia me conhecer. Tal como o diabo se apodera da sombra de Peter Schlemihl, também o professor retirava meu nome desde o início da lição. Não deveria mais ser chamado. Quieto, ocupei-me até o toque da sineta. Mas foi tudo em vão. (Ibid, p 83$84)$.

Em outro lampejo, intitulado O Carossel, Walter envolve-nos com a atmosfera onírica de uma experiência vertiginosa, salta aos olhos os detalhes que são revelados através de uma escrita minuciosa:

O tablado com os solícitos animais girava muito próximo ao chão. Tinha a altura na qual melhor se sonha sair voando. A música irrompia, e o menino girava às sacudidelas, afastando-se da mãe. No início, tinha medo de abandoná-la. Mas depois percebia como era fiel a si próprio. Estava sentado no trono como leal soberano, governando o mundo que lhe pertencia. Nas tangentes, árvores e indígenas formavam uma guarda de honra. De súbito, reaparecia a mãe nalgum Oriente. Em seguida, emergia da floresta virgem uma copa de árvore, tal como o garoto a vira há milênios, tal qual a via 
justamente agora. Seu animal se macomunava com ele: como um Árion mudo, ele se ia montado em peixe mudo, um Zeus taurino de madeira o raptava como à imaculada Europa. Fazia tempo que o eterno retorno das coisas se tornara sabedoria infantil, e a vida uma antiquíssima embriaguez do poder com a orquestra mecânica no centro. Tocasse mais lentamente e o espaço começaria a balbuciar e as árvores a hesitar. O carrossel se tornaria terreno inseguro. E a mãe ficava lá como a haste tantas vezes abordada, à qual, aterrisando, o menino lançava as amarras de seu olhar. (Ibid, p.106).

O projeto Arqueologia de saberes, imagens e afetos ${ }^{6}$, desenvolvido no âmbito na disciplina Arte e Educação, inspira-se livremente em Benjamin, tentando lastrear pistas que possam fazer sentido para que a experiência ocorra no e com o sujeito e não fora dele, restituindo-lhe, através e com as práxis poéticas e as narrativimagens, o espaço e o tempo da memória, do território do brincar, da infância e do olhar na formação docente. Uma pedagogia plena de poiésis, ou melhor, uma pedagogia poética.

A práxis poética "Memória e Infância: territórios do brincar na formação de professores" caminha na trilha deixada pelas memórias do pequeno Walter, reposiciona a palavra e a imagem em uma unidade do pensamento e propõe pensar a formação docente a partir de geografias outras. As veredas que apontam para as narrativimagens partem também de algumas outras costuras e referências que remetem ao tema da infância, que foi objeto de abordagem em sala de aula.

Nesse percurso, encontramos com o livro "Memórias inventadas: a infância”, do poeta goiano Manoel de Barros, e tivemos, na ocasião, o privilégio de ler coletivamente suas estórias e imaginar aqueles espaços e tempos em um exercício de reflexão e criatividade. Demos um salto, inspirados pelo poeta, e

\footnotetext{
${ }^{6} \mathrm{O}$ projeto Arqueologia de Saberes, Imagens e Afetos busca ordenar uma série de ações e experiências que colocam em evidência, sobretudo, memórias, processos simbólicos de subjetivação e criação, capturas e leituras do real na sua expressão poética. As práxis poéticas e as narrativimagens integram o projeto e nomeiam essas ações.
} 
escrevemos o que nomeamos de "Histórias Inventadas", um livre processo de escrita cujo único compromisso era com o exercício de fabulação. Depois, encontramos com o filme de animação "A flor mais grande do mundo", baseado na obra "A maior flor do mundo", de José Saramago, que se transforma - o escritor português - em personagem e conta-nos que uma vez teve uma ideia para um livro infantil: inventou uma história sobre um menino que faz nascer a maior flor do mundo. O filme de animação do espanhol Juan Pablo Etcheberry narra a história desse menino e num dado momento Saramago pergunta: se as histórias para crianças passassem a ser leitura obrigatória para os adultos? Seriam eles capazes de aprender realmente o que há tanto tempo têm andado a ensinar?

Prosseguimos na nossa errância e encontramos o documentário "Território do Brincar”, que apresenta o universo lúdico infantil de Norte a Sul do país. Segundo a educadora Renata Meirelles, coordenadora do projeto, uma das propostas é aproximar o adulto do universo infantil e, ao optar por olhar o brincar, faz-se uma aposta no que há de mais belo e potente na infância. Como desdobramento, trouxemos para a sala de aula as brincadeiras preferidas, um momento de troca intensa de experiências em que revivemos memórias sutis da infância e transformamos, literalmente, o espaço e o tempo da disciplina Arte e Educação em um território do brincar.

Visando ampliar os sentidos desse contexto formador, o discente foi incentivado a revisitar as suas memórias, as reminiscências mais profundas e sutis, os sentimentos, as emoções, as imagens e os espaços que permearam a sua infância, e, a partir do seu território do brincar, mergulhassem na escrita, em forma de narrativa, desse conjunto de experiências. Também, junto com a narrativa, foi entregue uma imagem fotográfica que expressa a síntese da experiência do seu território do brincar. A imagem, em si, poderia ter sido apropriada do arquivo de imagens da sua infância ou criada exclusivamente para o contexto da jornada.De igual forma, foi sugerido que as imagens disponíveis, na internet, não fossem utilizadas. Majoritariamente, constatou-se que as imagens foram criadas e não 
resgatadas de álbuns de família ou arquivos. A imagem que integra a narrativimagem é uma escolha do discente.

Foi ain da ressaltado o livre processo de criação da narrativa e captura do registro fotográfico, também que fossem guiados pela intuição, pelo que realmente é parte constituinte de cada um, percebessem que a narrativa é um processo de escrita que ressalta o nosso universo das miudezas e de traços que revelam mais da nossa natureza subjetiva e do conteúdo soterrado pelo tempo, ou seja, a memória. Voassem alto em direção a eles mesmos. Lembrassem-se dos textos: Notas sobre o Saber da Experiência, do Jorge Larrosa (2015), o Narrador e Experiência e Pobreza, de Walter Benjamin (1994) e da Narrativa como Método, de Nilda Alves (2000), entre outros autores, e também das nossas trocas, sobretudo, as simbólicas, no território da disciplina Arte e Educação.

\section{Narrativimagens: por uma arqueologia das infâncias ${ }^{7}$}

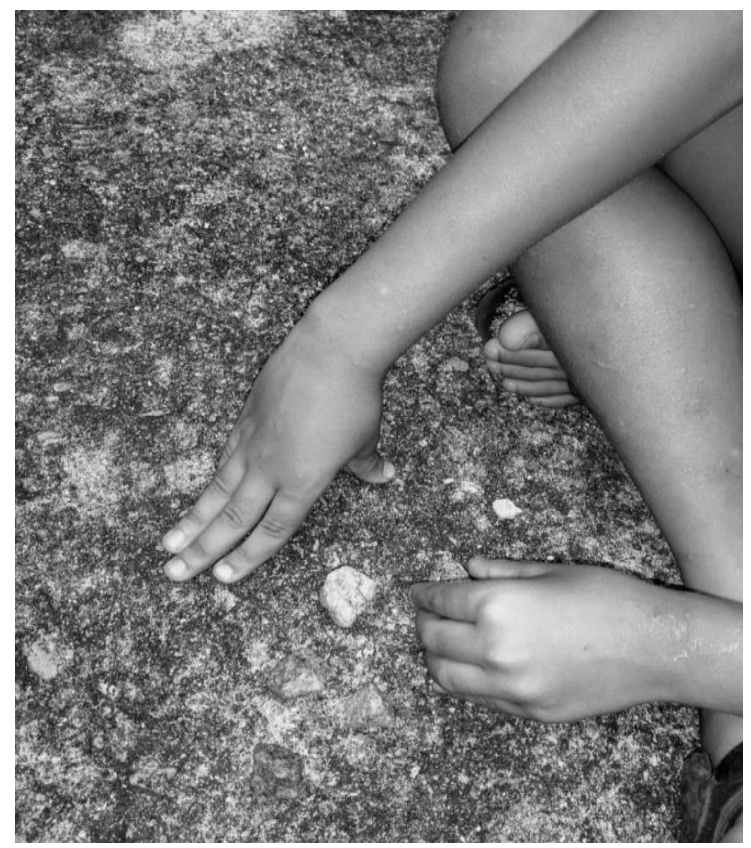

Foto: Cileide da Silva Lima

\footnotetext{
${ }^{7}$ As narrativas não sofreram edição e parcialmente foram revisadas. Uma opção ética e político-pedagógica que preserva a natureza singular e a expressão da palavra escrita do discente. As narrativas imagéticas são autorais e não foram editadas a fim de manter a mesma coerência, e a seleção fotográfica foi uma prerrogativa do discente.
} 
Brincadeiras de infância - Quando se fala na infância, logo me lembro da minha, tive uma infância difícil, fiquei órfã de pai ainda muito pequena, minha mãe pouco podia nos dar, mas como toda criança não precisei de muito para me divertir. Lembro-me que quando chegava da escola, tirava o meu uniforme e saia para brincar na rua. Havia várias brincadeiras de rua, brincava de todas, pega-pega, esconde-esconde, queimado, entre outras. Eu não tinha bonecas caras, as minhas eu mesmo fazia, bastava pano e agulha. De todas as brincadeiras tinha uma em especial, que reuníamos as meninas e ficávamos a tarde toda brincando, era a brincadeira das três Marias, cada uma das meninas já tinha as suas pedrinhas, bem gastas de tanto a gente brincar. E sem precisar de muito, só de algumas pedrinhas de construção e um espaço no chão. Não ligava se era em chão de terra batida ou de cerâmica, eu só queria brincar, ficava horas com as pernas cruzadas, sem me queixar se estavam dormentes ou não. A brincadeira era divertida e competitiva, tínhamos que empurrar pedrinha por pedrinha para dentro da caverna, que fazíamos com nossas próprias mãos, passava de fase quem empurrava todas as pedras para dentro da caverna sem que resvalassem umas nas outras, nas próximas fases a dificuldade aumentava, as pedras teriam de ser empurradas de duas em duas e assim sucessivamente até que houvesse um vencedor. Cileide da Silva Lima

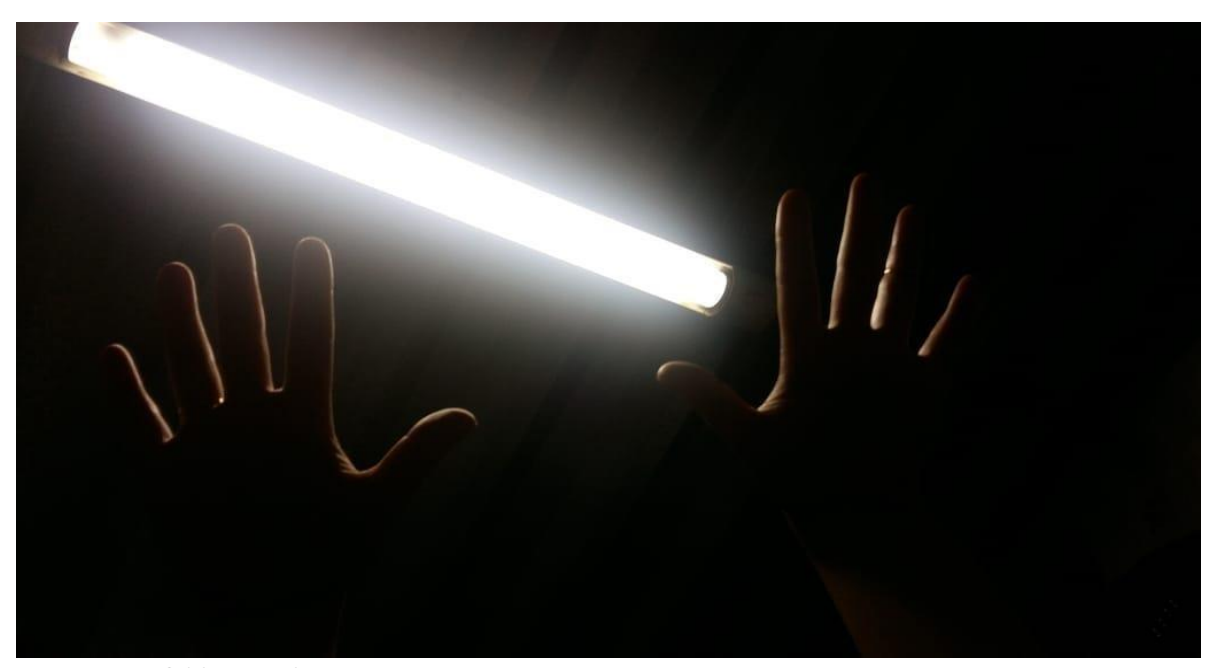

Foto: Luanna Silva Alves

Mexe, mexe, mexe com as mãos - Minha mãe sempre dizia que a melhor brincadeira era aquela que não tinha brinquedo. A melhor brincadeira era quando o brinquedo 
éramos nós mesmos. Pois bem, eu sempre fui meu próprio brinquedo. Brincava com os meus cabelos, meus pés, minhas unhas, meu rosto e minhas mãos... Ah! As minhas mãos. Era utilizando as minhas mãos que eu e a criançada da minha creche - Nosso Lar - brincávamos a maior parte do tempo. Babalu; Com quem será?; Adoleta; Porrinha; Popoye; Pedra, papel e tesoura; Cama de gato foram brincadeiras que fizeram parte de toda a minha infância. Brincávamos em qualquer lugar na creche, escola, parquinho, play, escadas do prédio e em casa. E o melhor de tudo era o fato de não gastar nada para brincar, não era um objeto que precisava ser carregado e muito menos esquecido, o que facilitava a diversão. As brincadeiras de mãos quase sempre envolvem músicas e coreografias, o que contribuí muito para o físico e para mente das crianças e dos adultos. Sim, adultos. Porque todos os seres humanos possuem mãos, o que automaticamente os qualificam para brincadeira. As brincadeiras também serviam (e ainda servem) para decidirmos posições a serem ocupadas, como “Quem começa?” e/ou “Qual é a ordem?”, para resolver questões assim tínhamos Pedra, papel e tesoura e Ímpar ou Par, lembro-me que levei anos para entender o sentido desta última, matemática não era e continua não sendo o meu forte, pasmem. Mas não me abalava, colocava um sorriso no rosto, fazia cara de quem estava entendendo e simplesmente aceitava quando meu/minha amigo(a) dizia ser um ou outro. Bons tempos... Naquele tempo eu não tinha noção do quanto ser criança é maravilhoso e mágico, eu até brincava, todavia, sinto que não brinquei o suficiente. Sorte que nunca é tarde e já que temos mãos, vamos brincar de Adoleta?

\section{Luanna Silva Alves}




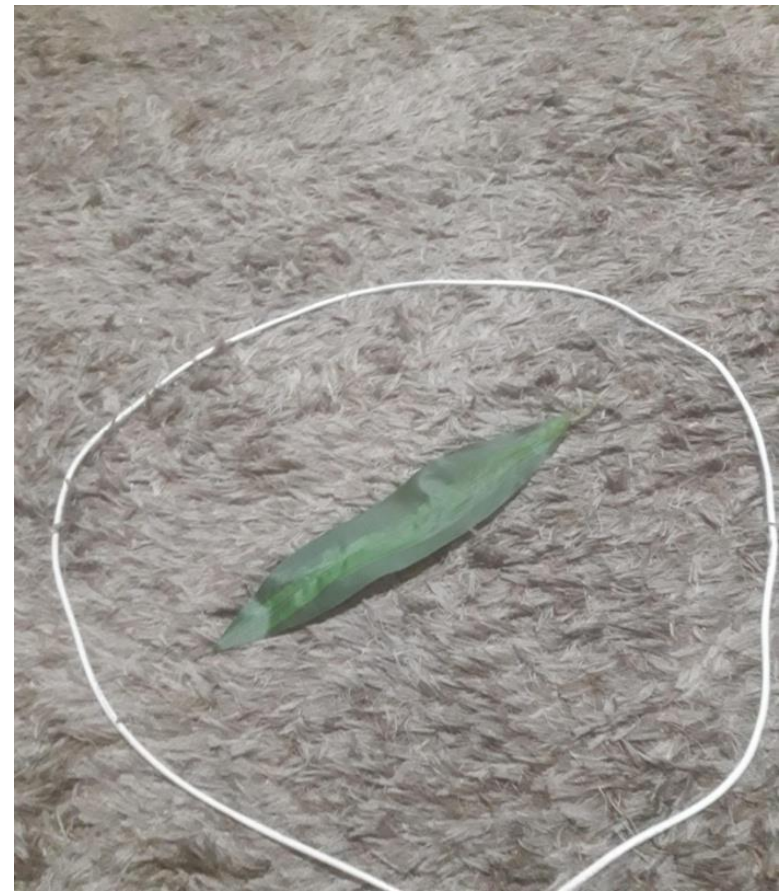

Foto: Fabiane Santos de Paiva

Brincadeira de criança - Quando criança era uma menina que adorava brincar na rua, tinha muitos amigos e nos reuníamos toda noite para brincar. Brincávamos de todo o tipo de pique, jogava futebol, bola de gude, vôlei... Meus pais sempre ficavam sentados conversando com os vizinhos. Na rua em que eu morava a vizinhança era muito unida. Até mesmo os adultos tinham seus jogos: jogavam baralho, dominó e sinuca. A diversão era completa!Num final de semana ensolarado era garantida a brincadeira de soltar pipa ou o famoso ratinho feito de folha de caderno: era maravilhosa aquela adrenalina de cortar as outras pipas e correr atrás da pipa voada. Nada impedia nossa rotina de brincar à noite, nem mesmo a chuva: aí brincávamos de adedanha, adoleta, mesmo uma roda de conversa se transformava numa brincadeira. Enfim, de todas as brincadeiras a que eu mais gostava era pique bandeira. Se fosse para eu escolher a brincadeira eu só escolheria essa. Minha infância foi muito bem aproveitada. Curti muito, se eu pudesse e tivesse oportunidade brincaria até hoje da minha brincadeira preferida. Fabiane Santos de Paiva 


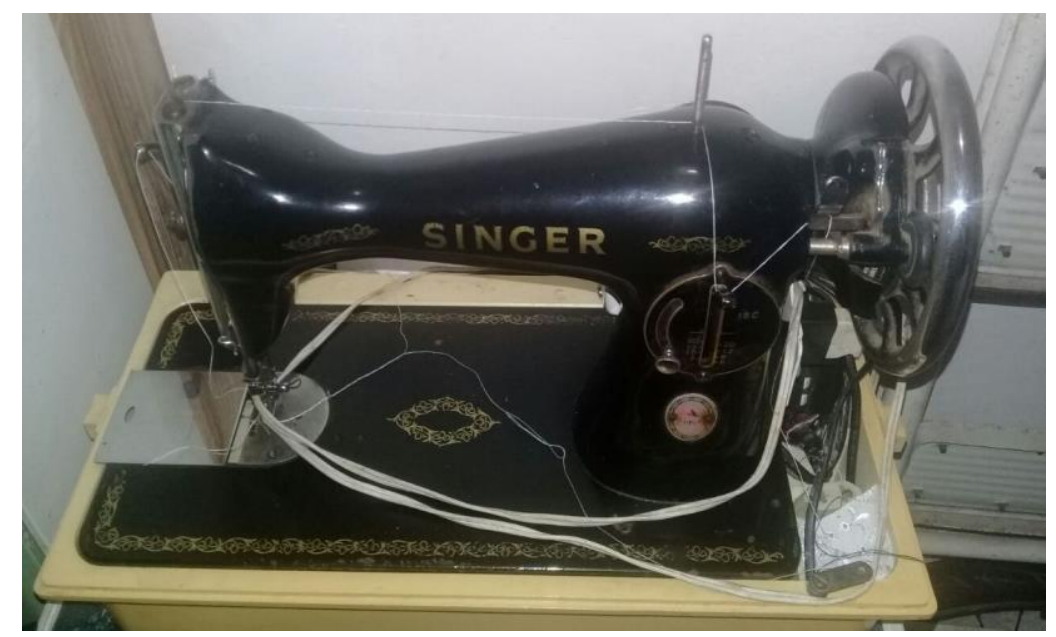

Foto: Valéria Nazaré dos Santos Silva

Meu território do brincar- Posso dizer que desfrutei da minha infância como quem come uma barra de chocolate com muita vontade. Lembro come se fosse ontem o dia que eu e meu irmão soltamos os porcos e eles saíram correndo para comer as verduras da horta da minha mãe, aquilo tudo era muitoengraçado, havia uma senhora que morava no mesmo quintal que nós, ela vinha correndo nos entregar para a mamãe, dizia ela sempre a mesma coisa: "Sueli, os meninos estão subindo nas árvores, mexendo com os porcos, espalhando as folhas, se enterrando na areia e correndo dentro da minha casa..." Como eram boas aquelas travessuras, nós sabíamos que quando entrássemos em casa na hora do banho iríamos "entrar no couro" como dizia nossa mãe, mas não nos importávamos era tudo tão gostoso que valia a pena. Eu e meu irmão Válber éramos as duas primeiras crianças da família, os primogênitos em tudo, primeiros sobrinhos e primeiros netos. Meu irmão, o primeiro neto, e eu, a primeira neta, isso era tão importante para mim, todas as vezes que alguém perguntava quem éramos minha avó respondia com tanto orgulho... Ela era uma pessoa tão especial, tinha um jeito doce de andar, falar, ouvir, ensinar e até em se vestir. Foi a minha Rainha, eu chegava à casa dela gritando "VÓóó!!! E lá vinha ela toda linda com cheirinho de pó de arroz e leite de rosas, um coque cheio de grampos no cabelo ralo, eu pedia benção, dava dois beijos, um abraço e ela sorria... Entrava e ia procurar meu avô, com ele só pedia a benção mesmo, era sério, meio carrancudo, mas o amava do mesmo jeito, depois ia trás da minha avó, ficava a seguindo como se fosse uma sombra, a observava fazendo almoço, depois almoçávamos todos à mesa, era um silêncio tão grande exceto pelo barulho que meu 
avô fazia enquanto comia, confesso que era um tanto engraçado, eu me segurava para não rir porque se ele me visse rindo levaria bronca com certeza. Depois do almoço ajudava minha avó com a louça, olhava ela procurar pulgas nos cães e finalmente meu momento favorito que era quando ela ia para o quarto de costura, amava esse momento, ela ficava costurando as roupas, pregando botões e eu procurando tecido velho dentro de uma caixa enorme de papelão para ela fazer minha boneca, o quarto cheirava mofo, eu com alergia espirrava sem parar, mas mesmo assim amava aquele lugar. Quando ela terminava o que tinha que fazer, eu pegava os tecidos e ela começava a fazer minha boneca, eu prestava muita atenção em tudo, o que ela fazia era sagrado, foram tantas bonecas que ganharam vidas naquelas tardes de domingo, mas havia uma em especial que eu não esqueço até hoje... fui uma criança bastante turrona e vivia a brigar com meu padrasto então um dia fiquei de castigo no domingo e não pude ir à casa da minha avó, ela já havia ligado para perguntar o que tinha acontecido, minha mãe explicou. Quando entardeceu minha avó foi em casa e estava segurando uma sacola e advinha o que era? Isso mesmo, uma boneca, nossa como fiquei feliz... O tecido do corpo era cinza, cabelos e olhos pretos com a boca vermelha, para mim era a boneca mais linda do mundo, até o meu irmão chegar e cair em gargalhadas falando que a boneca se parecia com um tal de cadeirudo, eu como sempre saí aos prantos para atrás da minha avó, ela bem achou graça em tudo aquilo. Tinha muitas bonecas que ela me dava, mas aquela era especial, me lembro dela que era mesmo meio estranha... Porém, eu não me importava, o tempo passou, fui crescendo e não deixava de brincar de bonecas, quando completei 14 anos comecei um curso de corte e costura com foco em bonecas, aprendi a costurar e fiz minha primeira boneca, coloquei seu nome de flor e fui mostrar para minha avó e ela ficou muito orgulhosa, nessa época ela já não tinha mais aquela força de antes, costurava pouco por conta das dores nas pernas então eu ia todos os dias depois do curso ajudá-la e era tão divertido quanto nos tempos de criança... O tempo foi passando, minha avó foi adoecendo, teve depressão por não poder mais andar, mas ainda assim eu insistia em animá-la para costurar, às vezes ela me olhava com os olhos cheios de lágrimas e falava "agora é você quem cuida de mim”... O papel da criança havia se invertido, porém toda aquela situação, ainda assim para mim, era prazerosa, eu me sentia bem em fazer algo por alguém que eu tanto amava, eu via ali naquela mulher tão doce a minha infância, me lembro de muitas histórias que ela contava mesmo debilitada em uma cama... Minha Rainha, 
dona das melhores recordações da minha infância se chamava Diva Gonçalo dos Santos e hoje mora no céu, ainda tenho uma boneca que eu fiz e guardo com muito amor para um dia quando talvez tiver uma filha e ensiná- la a amar como minha Rainha me ensinou brincando e com muita sabedoria. Valéria Nazaré dos Santos Silva

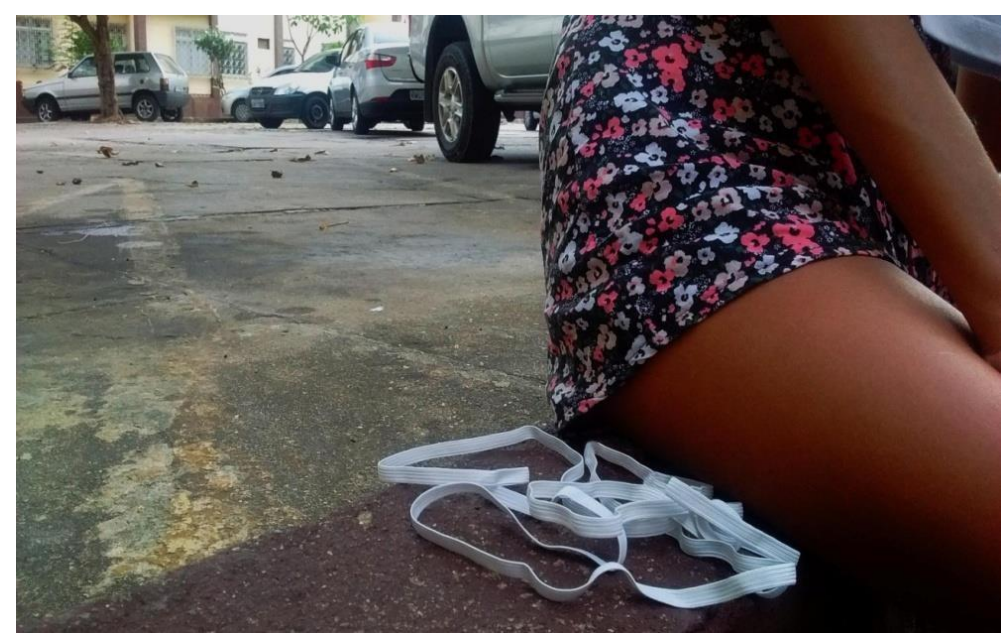

Foto: Roberta Pacheco de Freitas

Aos seis anos eu e minha família fomos morar no interior da Bahia, em uma cidade chamada Itabuna. Tudo era novo e a mudança me deixou muito feliz. Minha mãe matriculou a mim e minhas duas irmãs na escola pública do bairro, me lembro como se fosse hoje, ao chegar à escola a coordenadora nos levou para conhecer os espaços e eles eram enormes. No espaço aberto tinha quatro quadras, uma arquibancada, espaços com grama e areia, uma cantina cheia de guloseimas, horta e um pátio coberto. A sala de aula era bem colorida e a professora bem afetuosa. Como sempre fui muito falante, a diferença do sotaque foi rapidamente percebida por todos. Mas eles não viam isso como um problema e passaram a me "ensinar" as palavras que não entendia. Os amigos da escola também eram os amigos do bairro. Quando chegava do colégio, fazia o dever ou não, almoçava e descia para brincar. Era uma tarde inteirinha de brincadeiras, uma delícia. Eu ria muito, corria demais, gritava de susto, me escondia nos melhores esconderijos, pulava com muita energia, trocava segredinhos e paquerava o Neviton. Eram sempre várias brincadeiras numa tarde, mas brincar de elástico era quase religioso e tinha até campeonato e torcida. E essa rotina se repetia durante todas as maravilhosas tardes. Quando fiz onze anos, meus pais resolveram voltar para o Rio de Janeiro e mesmo com coração apertado eu voltei 
para o Rio, feliz por ser a minha terra natal e também por gostar de mudanças. Nova escola, novos amigos, novos hábitos e outros ritmos.Quando chegava da escola, fazia o dever e continuava em casa. Só nos fins de semana que descia para brincar. E as brincadeiras eram as mesmas, porém com algumas diferenças. Não podia fazer um monte de coisas, porque os vizinham não gostavam e reclamavam e as brincadeiras aconteciam no estacionamento, então era preciso ter muito cuidado. Quando uma amiga trouxe um elástico meus olhos brilharam, mas para a minha surpresa as meninas brincavam de elástico pulando e em silencio e na Bahia a gente brincava pulando/dançando e cantava. Essa diferença cultural não foi bem recebida pelas novas amigas, já que não aceitavam o meu jeito de brincar e da minha parte não conseguia me adaptar ao modo delas. A brincadeira do elástico passou a ser apenas uma das doces lembranças da Bahia que não esquecerei jamais. Roberta Pacheco

\section{de Freitas}

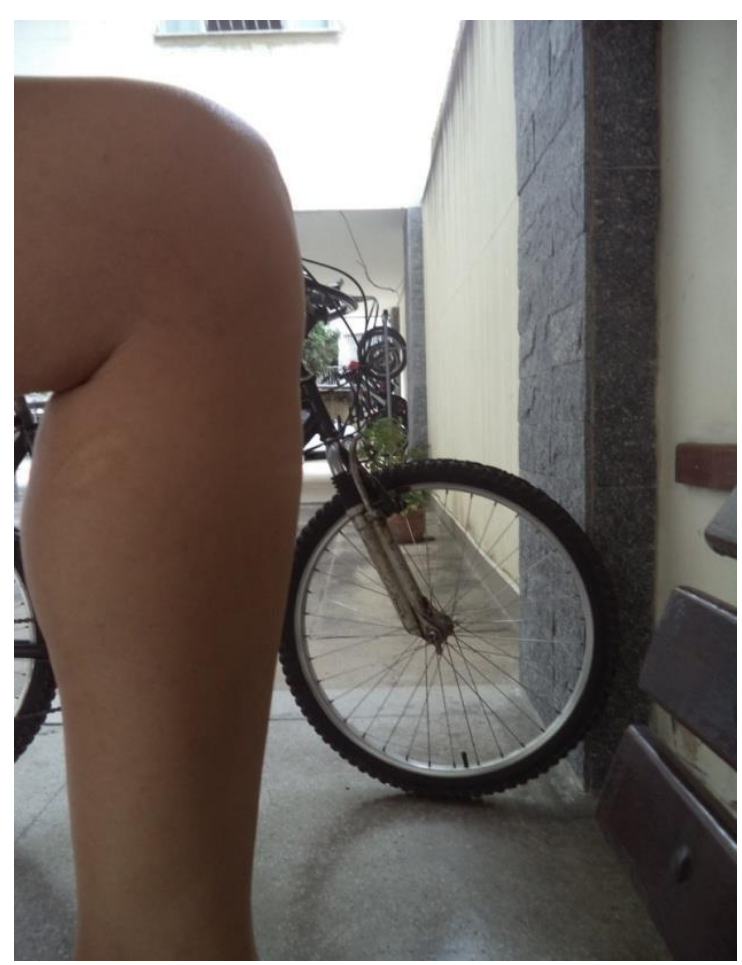

Foto: Mônica Conceição da Silva Santos

Eu e as magrelas- Era um novo ano, uma nova casa, novos amigos, nova escola. E para amenizar a saudade dos que ficaram para trás, eis que chega um presente de 7 anos! Era uma caloi! A mais linda e o último modelo da marca. Vermelha, com adesivo prateado e também com paralamas, ah! Aquele paralamas... Depois do sentimento de 
gratidão expressado pelo brilho nos olhos de viver aquela alegria, veio o desejo de tomar posse, de sair correndo com ela por aquele extenso chão de terra com alguns ou bastante buracos, para que todos vissem que naquela rua havia alguém com uma bicicleta caloi. Afinal era uma zona rural, um bairro novo, chamado Carapina, distrito de Serra, no Estado do Espírito Santo. Mas como era se equilibrar numa bicicleta? Bastaria subir e pedalar? Vendo os outros fazendo parecia tão fácil. Para isso existem os pais! Chegam com toda a confiança: - vai que eu estou te segurando! Pedala e olha pra frente! Não olha pra baixo! Estou aqui! Vai, vai... E de repente nasce uma nova ciclista! Com confiança executa a primeira curva e tibum! Do chão não passa, alguém um dia disse. Mas algo doía, ardia e havia sangue! Os pais correram para socorrer a mais nova ciclista da rua que fora agredida por aquele bendito paralamas que pegou na panturrilha, causando a escamação da derme e epiderme. Acabou o amor pela caloi. Pelo menos até passar a dor da perna e da alma, pois o medo paralisa. Os dias passam, as lembranças do dia mal se vão e o papai, abrindo mão de descansar no sofá, assistindo tv em preto e branco, desafia a filha a uma nova experiência: - Bora lá andar nessa bicicleta, eu comprei para você andar! Lá se vai mais uma tentativa e dessa vez com sucesso. De repente a medrosa ficou corajosa e andou por toda a rua de chão batido fazendo curvas e zigzag. A companhia da linda caloi vermelha proporcionou autonomia, pois em pouco tempo a rua da casa era pequena e os passeios foram se estendendo por outras ruas. A magrelinha já não servia apenas como brinquedo, mas também para ir ao mercadinho comprar pouca coisa e posteriormente ajudou a mamãe a perder peso se exercitando. E assim foi sendo parceira por muitos anos até que a evolução industrial abafou seu imponente design e recursos. A experiência com a bicicleta aparece em outros momentos da minha vida com outras perspectivas e objetivos. Ainda hoje, uso a bicicleta como meio de transporte e como um modo de entretenimento, mas sempre que sento numa bike me permito viver a sensação de liberdade e autonomia do pensamento e do corpo. $\mathrm{E}$ com mais prudência, o zigzag ainda acontece, pra lembrar que a criança está aqui. Mônica Conceição da Silva Santos

\section{Práxis poética e os ecos benjaminianos nas/das narrativimagens}

O conceito de práxis é lido na companhia de Paulo Freire que absorve a perspectiva dos dialéticos modernos, superando a cisão entre teoria e 
prática. É uma síntese entre teoria-palavra e ação, perpassa toda a obra do educador pernambucano e está ligado às ideias de docência, educação libertadora, dialogicidade, autonomia, ação-reflexão, entre outros. Práxis, neste caso, assume uma dimensão histórica que busca compreender o homem, a mulher e o mundo na estreita relação que se estabelece entre um modo de interpretar a realidade e a vida e a consequente prática que advém desta leitura, visando a uma ação transformadora. Freire e Benjamin fazem, literalmente, uma aposta na humanidade e valorizam o olhar crítico diante de uma realidade que sufoca a experiência, os afetos, a esperança e a utopia. Nesse movimento de valorização do ser mais ${ }^{8}$, escavar e recordar a memória, no contexto do projeto Arqueologia de Saberes, Imagens e Afetos, não é um instrumento, mas, antes, o meio. As narrativimagens, em sua essência, respondem ao programa de filosofia de Benjamin, enquanto um despertar dos sonhos coletivos e uma escrita que tem uma fisionomia. Um aforismo realça a importância da abordagem fisiognômica em Benjamin (2006): "Escrever a história significa dar às datas a sua fisionomia" (Ibid, p.518), e essa forma é modelada com o que está na epiderme do seu tempo. A cultura do cotidiano, as imagens do desejo e fantasmagorias, os resíduos e materiais insignificantes têm a mesma escala de importância, para o filósofo berlinense, que os eventos, as ideias e obras de arte mais eloquentes.

$\mathrm{Na}$ ação de escavar e recordar vão sendo criadas imagens que já nascem autônomas diante da palavra, não são meras ilustrações das narrativas. É com essa vocação que emergem os instantes fotográficos de Cileide, Luanna, Fabiane, Valéria, Roberta e Mônica. Enquanto suporte, as imagens são responsáveis por imprimir, na captura de mundo, a sua marca e o seu sentido. A imagem atualiza a palavra, revela camadas ainda não lastreadas pelas reminiscências. Mais do que um mero registro, ela é em si a apresentação do conteúdo da memória que desponta das regiões mais recônditas. Benjamin (1995), ao escrever sobre o processo de escavação do passado, o compara à ação

\footnotetext{
${ }^{8}$ A vocação para a humanização, segundo Paulo Freire, é uma característica que se expressa na busca do ser mais, uma experiência que se lança no conhecimento de si, do mundo e afirma o princípio da conquista da liberdade.
} 
de revolver a terra e o uso das suas ferramentas:

Quem pretende se aproximar do próprio passado soterrado deve agir como um homem que escava. Antes de tudo, não deve temer voltar sempre ao mesmo fato, espalhá-lo como se espalha a terra, revolvê-lo como se revolve o solo. Pois "fatos" não são além de camadas que apenas à exploração mais cuidadosa entregam aquilo que recompensa a escavação. Ou seja, as imagens que, desprendidas de todas as conexões mais primitivas, ficam como preciosidades nos sóbrios aposentos de nosso entendimento tardio, igual a torsos na galeria do colecionador. E certamente é útil avançar em escavações segundo planos. Mas é igualmente indispensável a enxada cautelosa e tateante na terra escura. [...] A rigor, épica e rapsodicamente, uma verdadeira lembrança deve, portanto, ao mesmo tempo, fornecer uma imagem daquele que se lembra, assim como um bom relatório arqueológico deve não apenas indicar as camadas das quais se originam seus achados, mas também, antes de tudo, aquelas outras que foram atravessadas anteriormente. (Ibid, p. 239-240).

A realidade sempre foi interpretada por meio das informações sugeridas pelas imagens. As pinturas do período paleolítico comprovam essa tese ao se constituírem em um documento valioso do despertar da consciência humana. As imagens fotográficas desfrutam uma autoridade e uma presença sem precedentes na sociedade contemporânea. "Uma foto não é apenas uma imagem (como uma pintura é uma imagem), uma interpretação do real; é também um vestígio, algo diretamente decalcado do real, como uma pegada ou uma máscara mortuária" destaca Susan Sontag (2004, p. 170), que assinala também o efeito fragmentário causado pela exploração e duplicação fotográfica do mundo, que passou cada vez mais a se parecer com aquilo que as câmeras capturam. Ampliando a reflexão, a imagem fotográfica é um certificado, como diria Roland Barthes (2015), de presença ou, em outras palavras, coloca uma presença imediata no mundo. Um real que não se pode mais tocar, mas que está ali nos afetando, ou seja, produzindo afetos. 
A fotografia não apenas copia o real, recicla-o. Coisas e fatos, na condição de imagens fotográficas, recebem usos, destinos e significados outros. As imagens que compõem o acervo das narrativimagens não estão vinculadas à lógica de consumo e produção de imagens na contemporaneidade, ou seja, o narcisismo, a compulsão e a despersonalização da nossa relação com o mundo. Ao contrário, buscou-se na imagem a síntese de uma experiência e não o seu múltiplo, identificada como revelação de uma auto(biografia) ou de uma história em andamento que amplifica contextos que se solidarizam na cumplicidade educadora. Uma escolha político-poéticopedagógica que observa as imagens como rastros poderosos de uma existência e as pensa juntamente com Sontag (2004): "Se pode haver um modo melhor para o mundo real incluir o mundo das imagens, vai demandar uma ecologia não só de coisas reais mas também de imagens” (Ibid, p. 196).

As narrativimagens são registros de uma época, não falam apenas de uma experiência individual, mas são, sobretudo, a palavra e a imagem comunicando uma experiência coletiva. Talvez, no futuro, sejam fontes importantes para outros pesquisadores. Os discentes, em sua grande maioria, com raras exceções, ocupam a base da pirâmide social. A narrativimagem de Cileide, que abre a seção intitulada "Narrativimagens: por uma arqueologia das infâncias", apresenta um recorte da imagem do corpo de uma criança. As mãos estão no registro que recria a cena da brincadeira preferida, as três Marias. É como se essas mãos fossem as de Cileide. A infância difícil é uma marca na sua jornada, assim como a morte prematura do pai. A imagem do corpo aparece em muitas narrativimagens, como, por exemplo, na narrativimagem de Luanna em que o corpo é a própria brincadeira, um suporte de alegria e de autoconhecimento. Na fotografia estão as mãos, que simbolizam o seu encontro com o mundo através do brincar; Fabiane destaca a infância feliz, o encontro com as crianças para brincar a noite, o sentimento de pertencimento ao lugar, o bom convívio da vizinhança e as brincadeiras dos adultos; Valéria compara a sua infância a uma barra de chocolate, tal o prazer que desfruta das suas lembranças do tempo de criança. As travessuras estão 
presentes, assim como uma figura singular que irá marcar definitivamente a história da sua vida: a sua avó, que costurava as bonecas de pano; Roberta compartilha a luminosidade do interior da Bahia, os recantos da escola - um espaço colorido e pleno de experiências -, a presença dos afetos nesse ambiente de formação, mas, sobretudo, há o sentimento de liberdade do brincar. Na fotografia, novamente o corpo de uma criança e ao seu lado o elástico, uma representação, explorada na narrativa, que demarca as diferenças do nordeste e do sudeste em suas formas de encantamento com o objeto da brincadeira; Mônica compartilha memórias que são comuns a muitas crianças, o encontro com a primeira bicicleta - a caloi vermelha. Os momentos sofridos desse aprendizado e a presença do pai são marcas da experiência na sua criança. Um recorte do corpo se faz mais uma vez presente.

Benjamin (1994) discorre no ensaio Brinquedo e Brincadeira, de 1928, que a experiência de repetir é a essência da brincadeira, "nada lhe dá tanto prazer como brincar outra vez" (Ibid, p.252). O filósofo berlinense lembra que Freud acreditava ter descoberto nesse impulso um "além do princípio do prazer", e também observa que toda experiência profunda deseja a repetição e o retorno, isto é, a restauração de uma situação original que foi seu ponto de partida. Citando Goethe, mais adiante, ele escreve: “Tudo seria perfeito, se pudéssemos fazer duas vezes as coisas: a criança age segundo essas palavras de Goethe” (Ibid, p.253). A criança não quer fazer a mesma coisa apenas duas vezes, mas sempre denovo, destaca Benjamin, que percebeque na origem dos hábitos está a brincadeira.

Pois é, a brincadeira, e nada mais, que está na origem de todos os hábitos. Comer, dormir, vestir-se, lavar-se, devem ser inculcados no pequeno ser através de brincadeiras, acompanhados pelo ritmo de versos e canções. E da brincadeira que nasce o hábito, e mesmo em sua forma mais rígida o hábito conserva até o fim alguns resíduos da brincadeira. Os hábitos são formas petrificadas, irreconhecíveis, de nossa primeira felicidade e de nosso primeiro terror. (Id. Ibid).

Em outra passagem, Benjamin explora a imaginação das crianças e a 
presença dos adultos:

O mundo perceptivo da criança está marcado pelos traços da geração anterior e se confronta com eles; o mesmo ocorre com suas brincadeiras. É impossível situá-las num mundo de fantasia, na terra feérica da infância pura ou da arte pura. Mesmo quando não imita os utensílios dos adultos, o brinquedo é uma confrontação não tanto da criança com o adulto, como deste com a criança. Não são os adultos que dão em primeiro lugar os brinquedos às crianças? $\mathrm{E}$, mesmo que a criança conserve uma certa liberdade de aceitar ou rejeitar, muitos dos mais antigos brinquedos (bolas, arcos, rodas de penas, papagaios) de certo modo terão sido impostos à criança, como objeto de culto, que somente graças à sua imaginação se transformaram em brinquedos (Ibid, p250).

A obra de Benjamin ecoou, nutrindo o debate das mais diversas correntes e áreas do conhecimento. A década de 70 foi especial na renovação das suas ideias. Peter Bürger (2008), por exemplo, extraiu do conceito benjaminiano de alegoria uma "teoria da vanguarda" e Jünger Habermas, filósofo e sociólogo alemão que participa da tradição da teoria crítica e, assim como Benjamin, integrou a Escola de Frankfurt, enxergou através das lentes do "rabino marxista", as forças históricas da pós-modernidade.

Em sua obra monumental, o livro Passagens (2006), Benjamin conta a história material do século XIX através de suas expressões espirituais e físicas (a moda, a arte, a poesia, a arquitetura, as ruas e os interiores), percebidas à luz de certas categorias: teoria da história, teoria do fetichismo e teoria das imagens dialéticas. Ao abordar essas expressões, ele não pretende recontar a história do século XIX, mas sim mostrá-la. Com este procedimento - viaimagem -, abre-se a possibilidade parailimitadas atualizações dentro do que lhe desperta real interesse: os "trapos e lixos" dessa história e não os grandes feitos do século XIX.

A obra de Walter Benjamin tem sido objeto das mais variadas apropriações e leituras. De fato, existe uma riqueza teórica que não cessa em 
desvelar camadas de significação que se entrecruzam com várias correntes do pensamento moderno e que reverbera na contemporaneidade. Cada narrativimagem, assim como as ideias de Benjamin, é cercada de numerosos pontos de entrada. E todos esses pontos são acessíveis aos diferentes modos do olhar. Uma perspectiva progressista, no campo da formação, deve ter como premissa que o domínio da gramática visual também é uma conquista da cidadania, pois posiciona mulheres e homens em processo permanente de libertação. A práxis poética "Memória e Infância: territórios do brincar na formação de professores" reforça, num triplo movimento, o mundo, a palavra e a imagem, pois compreende que nessa tríade se instala a potência de uma educação humanista, progressista e libertadora.

\section{Referências}

ALVES, N. A narrativa como método na história do cotidiano escolar. In: CONGRESSO BRASILEIRO DE HISTÓRIA DA EDUCAÇÃO, 1., 2000, Rio de Janeiro. Anais... Rio de Janeiro: Editora da UERJ, 2000. p. 1-10.

BARTHES, Roland. A Câmara Clara. Rio de Janeiro: Nova Fronteira, 2015.

BENJAMIN, Walter. Obras Escolhidas. Trad. S.P. Rouanet. São Paulo: Brasiliense, 1994, v.1.

. Obras Escolhidas. Trad. R. Rodrigues Torres Filho e J.C. Martins Barbosa. São Paulo: Brasiliense, 1995, v.2.

Escritos sobre Mito e Linguagem. Trad. Susana Kampff Lages e Ernani Chaves. São Paulo: Editora 34, 2013.

Passagens. São Paulo: Editora UFMG, 2006.

BURGER. Peter. Teoria da Vanguarda. São Paulo: Cosac \& Naify, 2008.

LARROSA Jorge. Nota sobre a experiência e o saber da experiência. Leituras SME Campinas SP. Julho 2001. RPD - Revista Profissão Docente, Uberaba, v.11, n. 24, p. 53-67, jul/dez. 2011.

ROCHLITZ, Rainer. O Desencantamento da Arte: a filosofia da arte. Trad. Maria Elena Ortiz Assumpção. São Paulo: EDUSC, 2003.

SONTAG, Susan. Sobre a fotografia. Trad.Rubens Figueiredo. São Paulo: Companhia das letras, 2004. 
STRECK, D. R; REDIN, E; ZITKOSKI, J. J. (org). Dicionário Paulo Freire. Belo Horizonte: Autêntica Editora, 2018.

Recebido em junho de 2019. Aprovado em novembro de 2019. 